\title{
ENHANCEMENT OF METHANE OXIDATION WITH EFFECTIVE METHANOTROPHIC MIXED CULTURES
}

\section{Jayanthi Barasarathi* and Agamuthu P.}

Institute of Biological Sciences, University of Malaya 50603 Kuala Lumpur, Malaysia.

*jayne_barath@yahoo.com (Corresponding author)

Received on 15th December 2010, accepted in revised form 15th March 2011.

\begin{abstract}
The emission of $\mathrm{CH}_{4}$ from landfill is ranked third among the anthropogenic $\mathrm{CH}_{4}$ sources and ranged between 19-40Tg/yr. The Microbial oxidation of landfill methane plays a significant role in reducing the emissions to the atmosphere. This study was carried out to the investigate the impact of several parameters on methane $\left(\mathrm{CH}_{4}\right)$ oxidation, using compost as biocover. Addition of dedicated methanotrophic bacterial cultures was also included.. Experiments with different concentrations of methanotrophic mixed cultures ranging from $2.33 \mathrm{X} 10^{7}$ $\mathrm{CFU} / \mathrm{g}$ to $11.33 \mathrm{X} 10^{7} \mathrm{CFU} / \mathrm{g}$ showed that the highest oxidation rate with addition of $5.33 \mathrm{X} 10^{7} \mathrm{CFU} / \mathrm{g}$ was $4.166 \mathrm{X}$ $10^{3} \mathrm{ugg}^{-1} \mathrm{~h}^{-1}$. Experiments with different incubation temperature showed that highest oxidation rate of $4.166 \mathrm{X}$ $10^{3} \mathrm{ugg}^{-1} \mathrm{~h}^{-1}$ was at $35^{\circ} \mathrm{C}$. Similar oxidation rates were obtained with the addition of mixed culture at $60 \%$ moisture content. The highest bacterial count was obtained at $35^{\circ} \mathrm{C}$ at $12.33 \times 10^{7} \mathrm{CFU} / \mathrm{g}$ while lowest was at $45^{\circ} \mathrm{C}$. The moisture at $60 \%$ showed the highest bacterial count at $10.66 \times 10^{7} \mathrm{CFU} / \mathrm{g}$ whereas $30 \%$ moisture showed the lowest count at $3 \times 10^{7} \mathrm{CFU} / \mathrm{g}$. From this study we concluded that the addition of methanotrophic mixed culture gave a significant increase in methane oxidation compared to the control at the optimal temperature and moisture content.
\end{abstract}

(Key words: methane oxidation rate, methanotrophic mixed culture, compost, Biocover)

\section{INTRODUCTION}

The amount of Municipal Solid Waste (MSW) generated by human population is constantly growing, especially in developing countries. In Malaysia, the waste generation increased at $3 \%$ annually due to the rapid increase in population size and urbanization [1]. Most of the 30,000 tonnes/day of MSW are disposed into non engineered dumpsites. The emission of $\mathrm{CH}_{4}$ from landfill are ranked third among the anthropogenic $\mathrm{CH}_{4}$ sources and ranged between 19-40Tg/yr [2]. $\mathrm{CH}_{4}$ and $\mathrm{CO}_{2}$ are greenhouse gases (GHG) and $\mathrm{CH}_{4}$ is recognized as a potent $\mathrm{GHG}$ with a global warming potential (GWP) approximately 25 times that of $\mathrm{CO}_{2}$ [3]. The anaerobic decomposition of solid waste in landfill generates methane $\left(\mathrm{CH}_{4}\right)$ [4]. Malaysia shows an average of 1.3-7.5 L/kg/year of methane gas generation [5]. Malaysia's total green house gas (GHG) emission is equivalent to $1.5 \times 10^{11} \mathrm{CDE}$ in 2004 [5]. Global warming is caused by the passive release of GHG to the atmosphere leading to an increased radioactive forcing of the Earth's climate.

Previous studies have shown that microbial $\mathrm{CH}_{4}$ oxidation in landfill cover soil can be enhanced using substrates that are rich in organic matter, such as compost, rather than pure clay covers [6, 7]. Studies by Streese and Stegmann [8] on compost as a biofilter material for microbial degradation and they reported that high degradation rates of up to $63 \mathrm{~g}$ $\mathrm{CH}_{4} \mathrm{~m}^{-3} \mathrm{~h}^{-1}$. The microbial oxidation of methane plays a significant role in reducing the emission of methane to the atmosphere [9]. The oxidation of methane is usually mediated by a group of bacteria called the methanotrophs. Methanotrophs are aerobic microorganisms that use oxygen to oxidize $\mathrm{CH}_{4}$ to $\mathrm{CO}_{2}$ and biomass [10]. The methane produced in the landfill can be converted to carbon dioxide which is 25 times less harmful greenhouse gas by the oxidation process. Methane oxidation is controlled by several factors, including soil temperature, moisture, exture, as well as $\mathrm{pH}$ and nutrient content [11].

The aim of this study was to isolate methanotrophic bacteria that are capable of oxidizing methane gas and addition of these indigenous bacteria, as an effective microbial methanotrophic mixed cultures, to the biocover material under controlled conditions and analyze the methane oxidation rate. The studies also carried out included the impact of temperature and moisture content to determine the optimal condition for methane oxidation in tropical conditions.

\section{MATERIALS AND METHOD}

\section{Composting}

Compost was obtained by composting a mixture of $75 \%$ grass clippings and $25 \%$ cow dung. The materials were uniformly mixed to ensure even 
distribution of microbes for optimum composting. Heap method was used and composting was carried out under a shade. Water was added to the compost mixture to maintain the moisture level at $60 \%$. Aerobic condition was maintained by manual turning of composting mixture with daily mixing for the first 8 days and then mixing on alternate days. Temperature of the composting mixture was measured daily using electronic thermometer (Model Oregon Scientific SA880SSX). The moisture content was determined gravimetrically by oven drying compost at $104^{\circ} \mathrm{C}$ for 24 hours and expressed as the mass ratio of water to drying compost, following the ASTM (2004) procedure. The $\mathrm{pH}$ of the compost was measured using the $\mathrm{pH}$ meter model HANNA HI 8424. The organic matters was obtained according to ASTM 830-97 standard method. The total Carbon was obtained according to ASTM 777-87 (96) method and Total Nitrogen obtained according to ASTM E778-87 respectively.

\section{Isolation of methanotrophs.}

A modified Nitrate Mineral Salt( NMS) medium was used. The medium contained the following, per $1,000 \mathrm{ml}$ of distilled water: $\mathrm{NaNO}_{3}, 850 \mathrm{mg} ; \mathrm{K}_{2} \mathrm{SO}_{4}$, $170 \mathrm{mg} ; \mathrm{MgSO}_{4} \cdot 7 \mathrm{H}_{2} \mathrm{O}, 37 \mathrm{mg}$; and $\mathrm{CaCl}_{2} \cdot 6 \mathrm{H}_{2} \mathrm{O}$, $7 \mathrm{mg}$. After autoclaving, $10 \mathrm{ml}$ of phosphate buffer solution, $0.5 \mathrm{ml}$ of trace element solution, and $1 \mathrm{ml}$ of iron solution were added. The trace element solution ( $\mathrm{pH}$ 4.0) contained the following, per liter of distilled water: $\mathrm{ZnSO}_{4} \cdot 7 \mathrm{H}_{2} \mathrm{O}, 10 \mathrm{mg} ; \mathrm{MnCl}_{2} \cdot 4 \mathrm{H}_{2} \cdot 4 \mathrm{H}_{2} \mathrm{O}$, $3 \mathrm{mg} ; \quad \mathrm{H}_{3} \mathrm{BO}_{4}, \quad 30 \mathrm{mg} ; \quad \mathrm{Na}_{2} \mathrm{MoO}_{4} \cdot 2 \mathrm{H}_{2} \mathrm{O}, \quad 3 \mathrm{mg}$; $\mathrm{CaCl}_{2} \cdot 6 \mathrm{H}_{2} \mathrm{O}, 20 \mathrm{mg} ; \quad \mathrm{NiCl}_{2} \cdot 6 \mathrm{H}_{2} \mathrm{O}, \quad 2 \mathrm{mg} ; \quad$ and $\mathrm{CuCl}_{2} \cdot 2 \mathrm{H}_{2} \mathrm{O}, 1 \mathrm{mg}$. The phosphate buffer contained $1.4 \mathrm{~g}$ of $\mathrm{KH}_{2} \mathrm{PO}_{4}$ and $3.6 \mathrm{~g}$ of $\mathrm{Na}_{2} \mathrm{HPO}_{4}$ in $100 \mathrm{ml}$ of distilled water, $\mathrm{pH}$ 6.8. The iron solution contained $1.12 \mathrm{~g}$ of $\mathrm{FeSO}_{4} \cdot 7 \mathrm{H}_{2} \mathrm{O}$ in $5 \mathrm{ml}$ of $0.25 \mathrm{M} \mathrm{H}_{2} \mathrm{SO}_{4}$ in $100 \mathrm{ml}$ of distilled water. Methanotrophs were isolated in liquid culture as well as on agar plates. Enrichment cultures (3\% [vol/vol] $\mathrm{CH}_{4}$ atmosphere, NMS medium) from landfill soil samples where previously exposed to $\mathrm{CH}_{4}$ atmosphere were made and transferred several times to the NMS media.

Cells from these cultures were diluted in NMS medium (10-fold dilution) with a $3 \%$ (vol/vol) methane atmosphere to obtain pure cultures of methanotrophs. Cells from enrichment cultures medium were also spread on agar plates. The plates contained NMS medium and $1 \%(\mathrm{wt} / \mathrm{wt})$ Noble agar. After 2 weeks of incubation in 3\% (vol/vol) $\mathrm{CH}_{4}$, milky colonies from the agar plates were transferred into liquid medium. The absence of heterotrophic contaminants was tested by using complex agar ( $\mathrm{pH}$ 7.4) containing the following, per liter of distilled water: meat extract, $0.5 \mathrm{~g}$; Bacto Peptone, $0.5 \mathrm{~g}$; yeast extract, $0.1 \mathrm{~g}$; $\mathrm{KH}_{2} \mathrm{PO}_{4}, 0.1 \mathrm{~g}$; $\mathrm{NaCl}, 50 \mathrm{mg}$; and agar, $15 \mathrm{~g}$. The uniform cell shape of pure cultures was examined by phase-contrast microscope. [12].

Preparation of the methanotrophic bacterial mixed culture.

Three bacteria isolated from the above method were directly inoculated into $10 \mathrm{ml}$ NMS media in Wheaton bottle sealed with rubber septa and aluminium foil and $3 \%(\mathrm{v} / \mathrm{v})$ methane was introduced and incubated for 5 days until the culture turned turbid.

\section{Batch experiments}

Batch experiments were carried out using Wheaton bottles. All experiments were performed in triplicates. $20 \mathrm{~g}$ of compost were transferred into $125 \mathrm{ml}$ bottle and the methanotrophic bacteria mixed culture was introduced to the compost ranging from $0.5 \mathrm{ml}$ to $3 \mathrm{ml}$ concentration and sealed with rubber septa and aluminium seal to ensure gas tight. Then 15 $\mathrm{ml}$ of air from the headspace of the Wheaton bottle was withdrawn using an airtight syringe and replaced with $10 \mathrm{ml}$ of $\mathrm{O}_{2}$ gas $(99.98 \%$ purity) and $5 \mathrm{ml}$ of $\mathrm{CH}_{4}(99.9 \%$ purity) .This amount provided a mixing ratio of approximately $4 \%$ of $\mathrm{CH}_{4}(\mathrm{v} / \mathrm{v})$ and $8 \%$ $\mathrm{O}_{2}(\mathrm{v} / \mathrm{v})$ in headspace. $\mathrm{O}_{2}$ gas was added into the bottles to ensure that aerobic conditions prevailed during the experiment. The concentration of $\mathrm{CH}_{4}, \mathrm{O}_{2}$ and $\mathrm{CO}_{2}$ in the headspace was measured daily using Gas chromatography (Model Shimadzu 8A). The procedures was repeated with temperature and Moisture content variations.

\section{The Influence of incubation temperature}

To determine the influence of incubation temperature on methane oxidation, temperature ranging from $30^{\circ} \mathrm{C}$ to $45^{\circ} \mathrm{C}$ were tested. Each parameter was done in triplicates with bacterial culture where the cell count are fixed to $5.33 \pm 0.33 \times 10^{7} \mathrm{CFU} / \mathrm{g}$.

\section{The influence of moisture content}

To determine the influence of moisture content on the methane oxidation, moisture content ranging from $30 \%$ to $80 \%$ were tested, each parameter was done in triplicates with bacteria culture where the cell count are fixed to $5.33 \pm 0.33 \times 10^{7} \mathrm{CFU} / \mathrm{g}$. The moisture content of the compost was adjusted by adding sterile distilled water to increase the moisture content and by evaporating the water content to reduced the 
moisture content to the desired level. Samples were incubated at $35^{\circ} \mathrm{C}$.

Table 1: The physiochemical properties of the compost used for methane oxidation.

\begin{tabular}{|c|c|}
\hline Moisture content & $62.17 \pm 0.14 \% \mathrm{v} / \mathrm{v}$ \\
\hline $\mathrm{pH}$ & $6.33 \pm 0.12$ \\
\hline Organic matter & $63.6 \%$ \\
\hline Total Carbon & $20.30 \%$ \\
\hline Total Nitrogen & $1.20 \%$ \\
\hline Carbon: Nitrogen Ratio & 17 \\
\hline
\end{tabular}

$\mathrm{CH}_{4}$ Oxidation rate Calculation

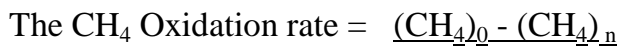
W X N

$\left(\mathrm{CH}_{4}\right)_{0}=$ Initial concentration of $\mathrm{CH}_{4}(\mathrm{ml})$

$\left(\mathrm{CH}_{4}\right)_{\mathrm{n}}=$ Concentration of $\mathrm{CH}_{4}$ at a time $\mathrm{n}(\mathrm{ml})$

$\mathrm{W}=$ the amount of compost $(\mathrm{g})$

$\mathrm{N}=$ time taken for complete methane oxidation (hours)

Statistical Analysis

Statistical analysis of data was carried out using SPSS Statistics version 17.00 for Analysis of Variance (ANOVA).

Figure 1 shows the $\mathrm{CH}_{4}$ oxidation rate of the compost with addition methanotrophic bacterial mixed culture. The highest oxidation rate was obtained at $4.166 \mathrm{X}$ $10^{3} \mathrm{ug} \mathrm{g}^{-1} \mathrm{~h}^{-1}$ with the addition of $5.33 \times 10^{7} \mathrm{CFU} / \mathrm{g}$ of methanotrophic mixed culture. The comparison with the control shows that the oxidation rate with $5.33 \mathrm{X}$ $10^{7} \mathrm{CFU} / \mathrm{g}$ of culture was almost double where the oxidation rate of control are $2.083 \mathrm{X} \mathrm{10}^{3} \mathrm{ug} \mathrm{g}^{-1} \mathrm{~h}^{-1}$. The oxidation rate shows a significant reduction after $5.33 \times 10^{7} \mathrm{CFU} / \mathrm{g}$ onwards.

The $\mathrm{CH}_{4}$ oxidation rate with the addition of $4.66 \mathrm{X}$ $10^{7} \mathrm{CFU} / \mathrm{g}$ culture shows a difference of almost $10 \%$ with the rate a $3.77 \times 10^{3} \mathrm{ug} \mathrm{g}^{-1} \mathrm{~h}^{-1}$. The addition of 6 $\mathrm{X} 10^{7} \mathrm{CFU} / \mathrm{g}$ onwards shows a gradual reduction in the $\mathrm{CH}_{4}$ Oxidation rate where the rate was $2.77 \mathrm{X}$ $10^{3} \mathrm{ug} \mathrm{g}^{-1} \mathrm{~h}^{-1}$ respectively. The highest $\mathrm{CH}_{4}$ oxidation rate by compost was obtained at the temperature of $35^{\circ} \mathrm{C}$ with the addition of bacterial culture, where the oxidation rate was $4.166 \times 10^{3} \mathrm{ug} \mathrm{g}^{-1} \mathrm{~h}^{-1}$ in Figure 2 . The comparison without addition of bacteria shows a

\section{RESULTS AND DISCUSSION}

Table 1 shows the physiochemical properties of the compost material. The compost moisture content was 62.17 and the $\mathrm{pH}$ 6.33.The ability of compost to retain the water is important to sustain the microbial population for the methane oxidation. According to Hilger and Humer[13] compost can offer a good water holding capacity to optimize $\mathrm{CH}_{4}$ oxidation. The $\mathrm{pH}$ of the compost should be neutral to slightly acidic to optimize the $\mathrm{CH}_{4}$ oxidation[14]. The organic matter of the compost was $63.6 \%$. According to the Chanton and Liptay [15] the methane oxidation is higher in organic rich soils. The C:N ratio of the compost was 17. A high maturity of the compost material is crucial for efficient $\mathrm{CH}_{4}$ consumption[16].

decrease of almost $50 \%$ in the oxidation rate. According to Fauziah et al., [17] the highest oxidation rate was obtained at $35^{\circ} \mathrm{C}$ for the batch experiment with the landfill cover soil. At $40^{\circ} \mathrm{C}$ the $\mathrm{CH}_{4}$ oxidation rate with addition of culture was $9.5 \%$ low compared to $35^{\circ} \mathrm{C}$ where the oxidation rate was

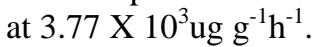

The oxidation rate at $30^{\circ} \mathrm{C}$ and $45^{\circ} \mathrm{C}$ were very low where the oxidation rate are $1.19 \times 10^{3} \mathrm{ug} \mathrm{g}^{-1} \mathrm{~h}^{-1}$. The comparison with $35^{\circ} \mathrm{C}$ shows that the oxidation rate was almost $71.43 \%$ slower. The incubation temperature is very important for the survival of bacteria and the activity of these bacteria to oxidize methane. The findings by Humer and Lechner [18] also indicated that at $35^{\circ} \mathrm{C}$, the methanotrophic activity was highest compared to the other incubation temperature studied ranging from $15^{\circ} \mathrm{C}-35^{\circ} \mathrm{C}$. Temperature can affect the $\mathrm{CH}_{4}$ solubility in water, which eventually alters the $\mathrm{CH}_{4}$ oxidation by the change the $\mathrm{CH}_{4}$ uptake rate [19]. 


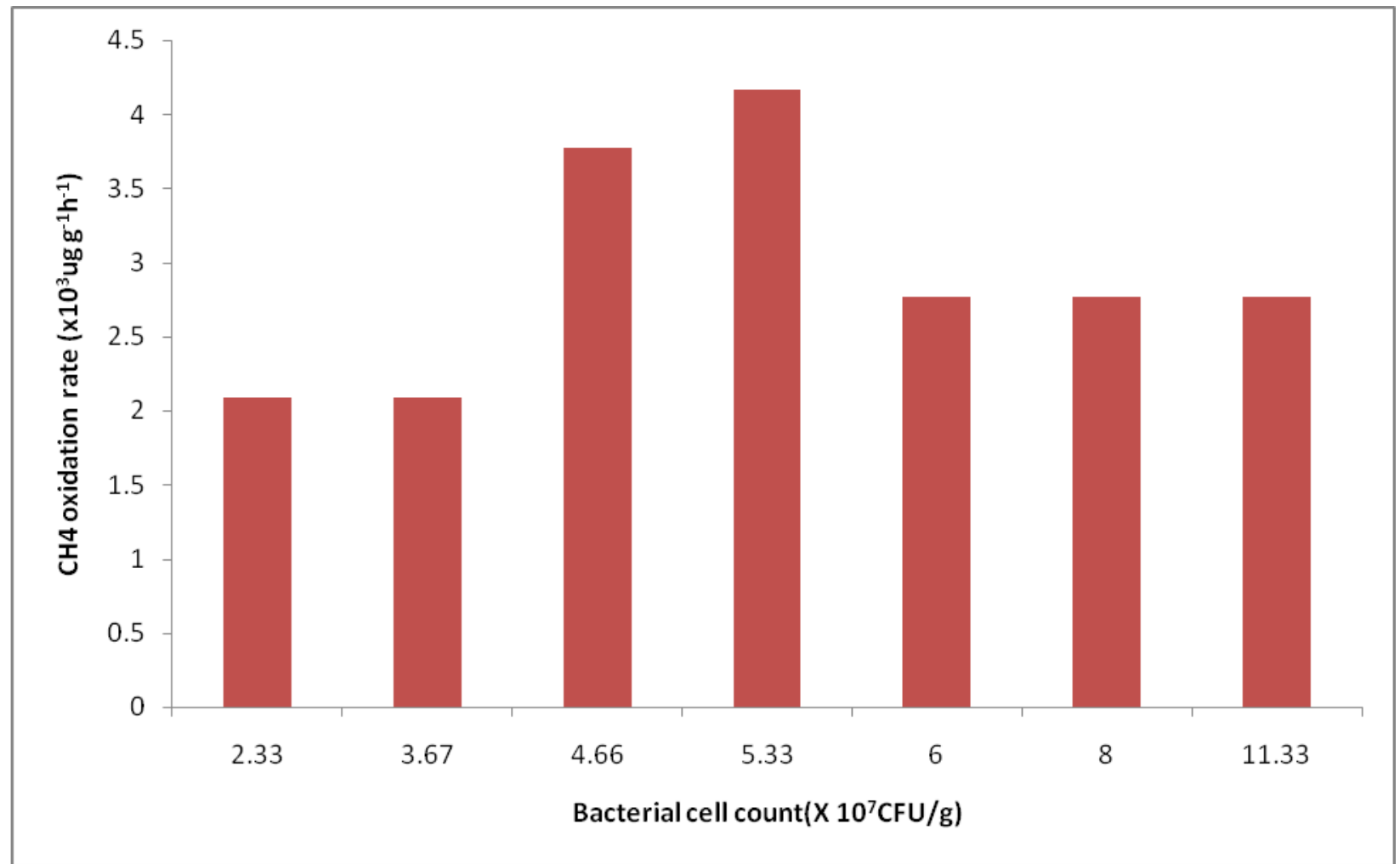

Figure 1: The $\mathrm{CH} 4$ oxidation rate with addition of different concentration of bacteria culture. 


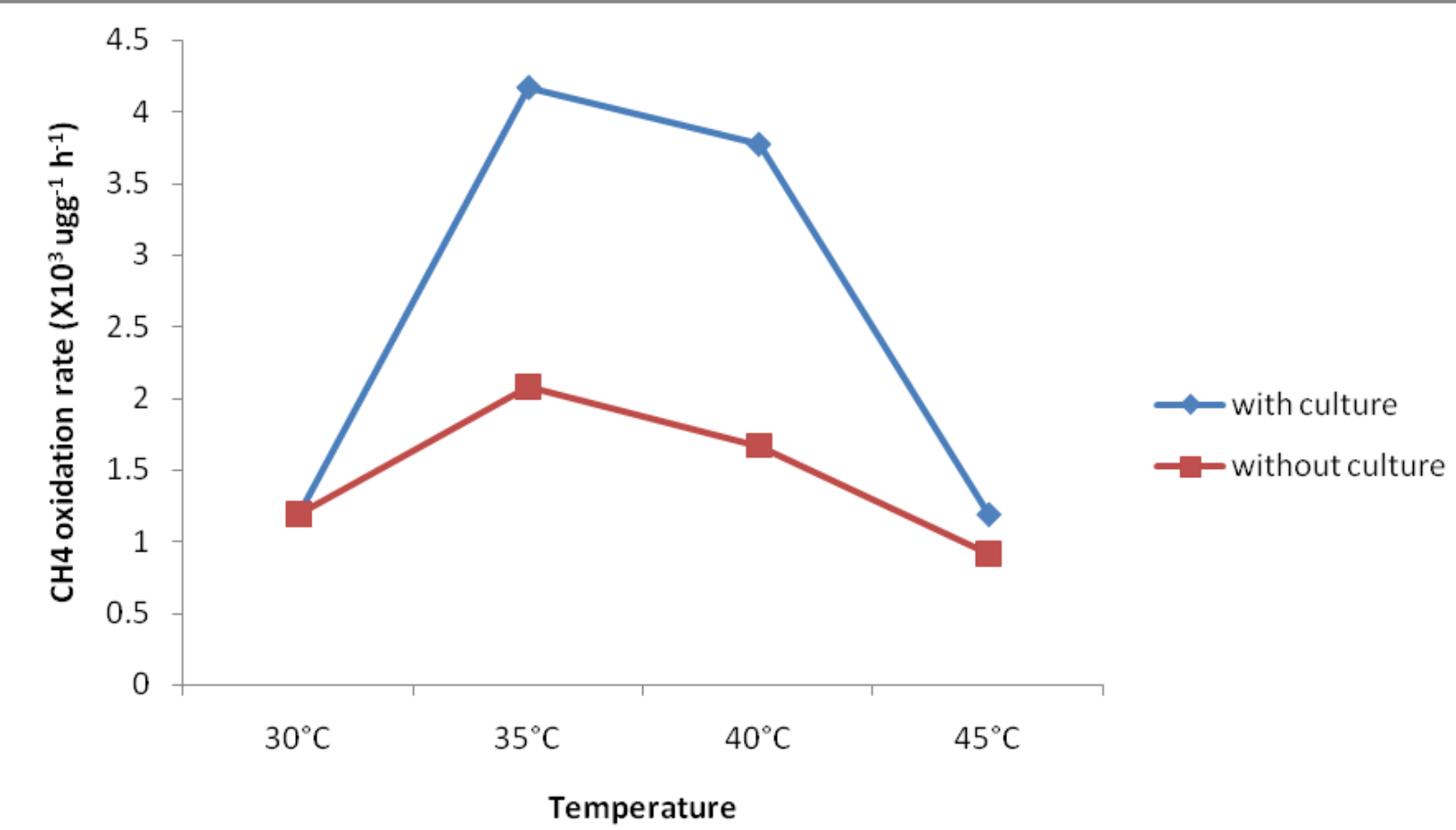

Figure 2: The Effect of temperature on methane oxidation rate with and without addition of bacteria culture to the compost

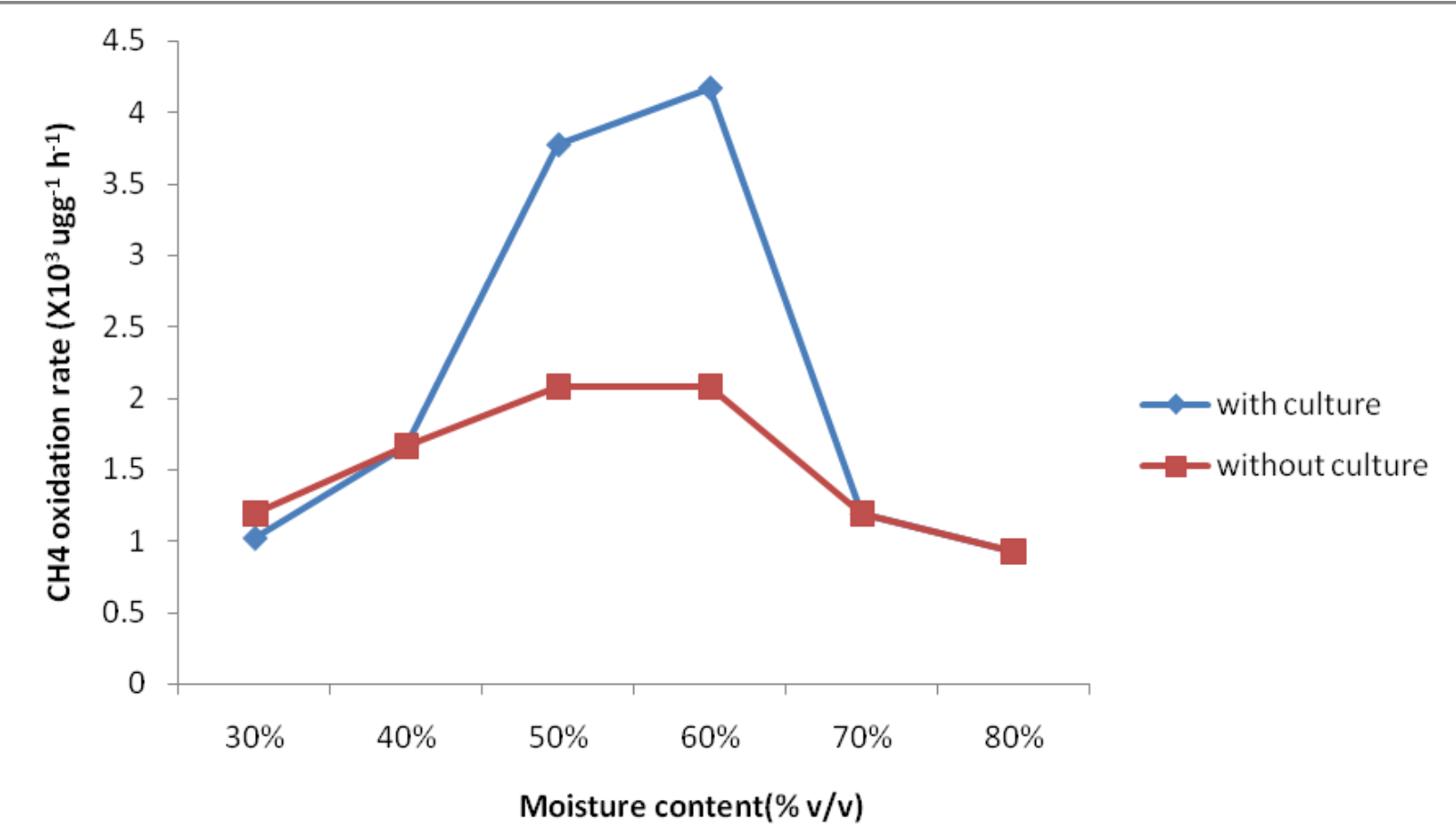

Figure 3: The Effect of moisture content on methane oxidation rate with and without addition of bacteria culture to the compost

Figure 3 shows the $\mathrm{CH}_{4}$ oxidation rate at different moisture content .The figure clearly shows that the highest oxidation was obtained when the moisture content was $60 \%$, with the addition of culture. This 
indicates that suitable moisture content is important for the methane to be oxidized. The oxidation rate was at $4.166 \times 10^{3} \mathrm{ug} \mathrm{g}^{-1} \mathrm{~h}^{-1}$ with the addition of bacteria culture. The Statistical analysis revealed that there were significant differences between with and without addition of microbial culture, at $60 \%$ moisture content.

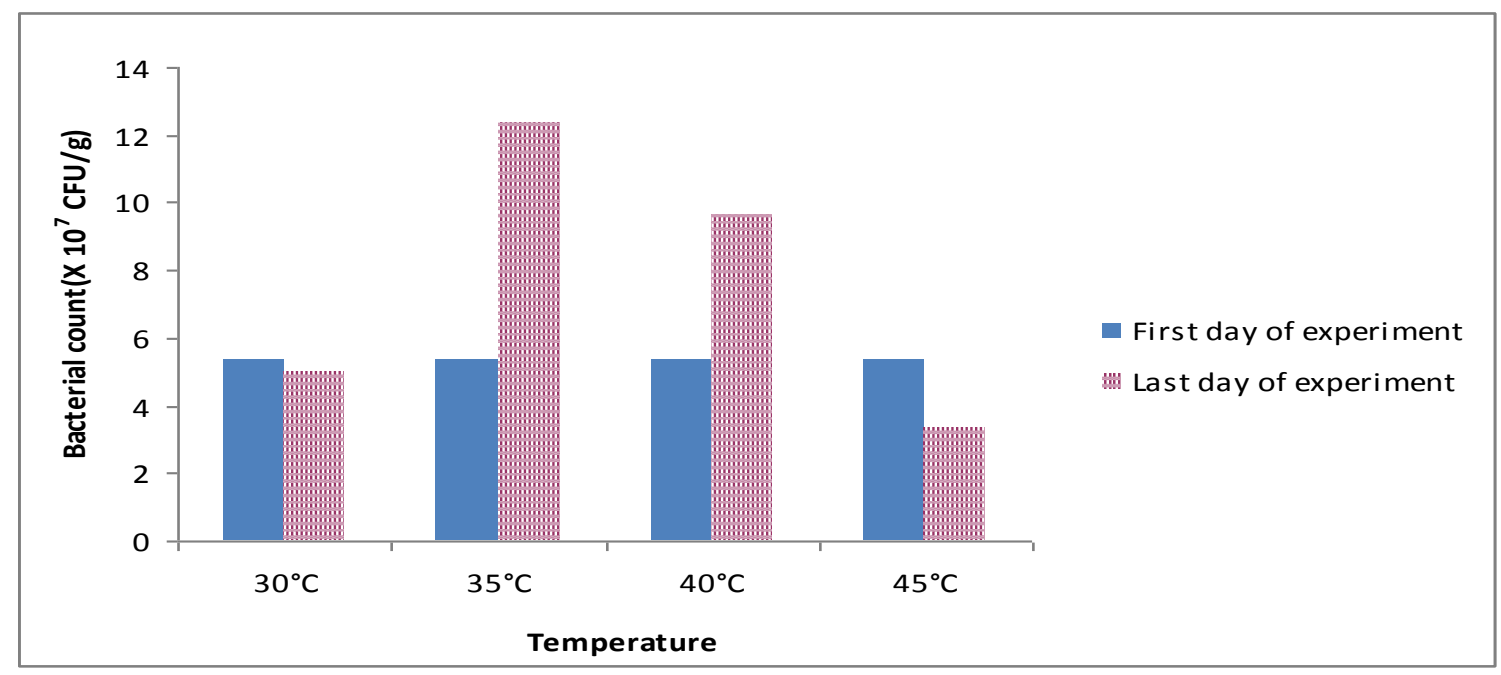

Figure 4: The bacterial count for the effect of temperature on $\mathrm{CH}_{4}$ oxidation with addition of bacterial culture.

At $40 \%$ moisture content the oxidation rate are 1.667 $\mathrm{X} 10^{3} \mathrm{ug} \mathrm{g}^{-1} \mathrm{~h}^{-1}$ with addition of culture which is very low compared to the $60 \%$ moisture content. The difference in the oxidation rate is almost $60 \%$ lower. This indicate that suitable water content is very important for the methane oxidation to occur .The water content of the cover soil is an important factor controlling the methane emissions from landfill[20, 21].

This indicated that the biocovers materials ability to retain water is important to sustain the microbial population for the $\mathrm{CH}_{4}$ oxidation. Inhibition effects on the methane oxidation at low moisture content have been reported [18]. The $\mathrm{CH}_{4}$ oxidation rate shows a gradual decrease when the moisture increased to $70 \%$ and $80 \%$ where the $\mathrm{CH}_{4}$ oxidation rate was $1.19 \times 10^{3} \mathrm{ug} \mathrm{g}^{-1} \mathrm{~h}^{-1}$ and $0.925 \times 10^{3} \mathrm{ug} \mathrm{g}^{-1} \mathrm{~h}^{-1}$ respectively. There is no significant difference between the control and with addition of microbial culture. Barlaz et al., [19] reported that the compost covers oxidized more $\mathrm{CH}_{4}$ in field trials, but warned that compost covers can also produce $\mathrm{CH}_{4}$ if the moisture content is too high.
The bacterial count from Figure 4 also indicated that at the end of the experiment the bacterial count was highest at $35^{\circ} \mathrm{C}$ where the counts was $12.33 \mathrm{X} 10^{7}$ $\mathrm{CFU} / \mathrm{g}$. At $40^{\circ} \mathrm{C}$ the counts was $10.663 \times 10^{7} \mathrm{CFU} / \mathrm{g}$. The difference in the bacterial count at end of the experiment was due to the incubation temperature where the methanotrophic bacteria grows best at $35^{\circ} \mathrm{C}$ compared to other incubation temperature.

The lowest count was obtained at $45^{\circ} \mathrm{C}$ where the counts was $3.33 \times 10^{7} \mathrm{CFU} / \mathrm{g}$. According to Pawloska [23] the methanotrophic bacteria prefers mesophilic conditions as shown in this study. The highest bacterial count was obtained when the moisture content is $60 \%$ shown in Figure 5. The counts was $10.66 \mathrm{X} 10^{7} \mathrm{CFU} / \mathrm{g}$. Boeckx et al [16] indicated that the water content widely regulates the activity of methanotrophic bacteria. The lowest bacterial count was obtained when the moisture content was $30 \%$ where the counting was $3 \times 10^{7} \mathrm{CFU} / \mathrm{g}$. Whalen et al [23]also indicated that a decrease in the methanotrophic activity when the moisture content are ranged from $30 \%$ to $50 \% \mathrm{v} / \mathrm{v}$. 


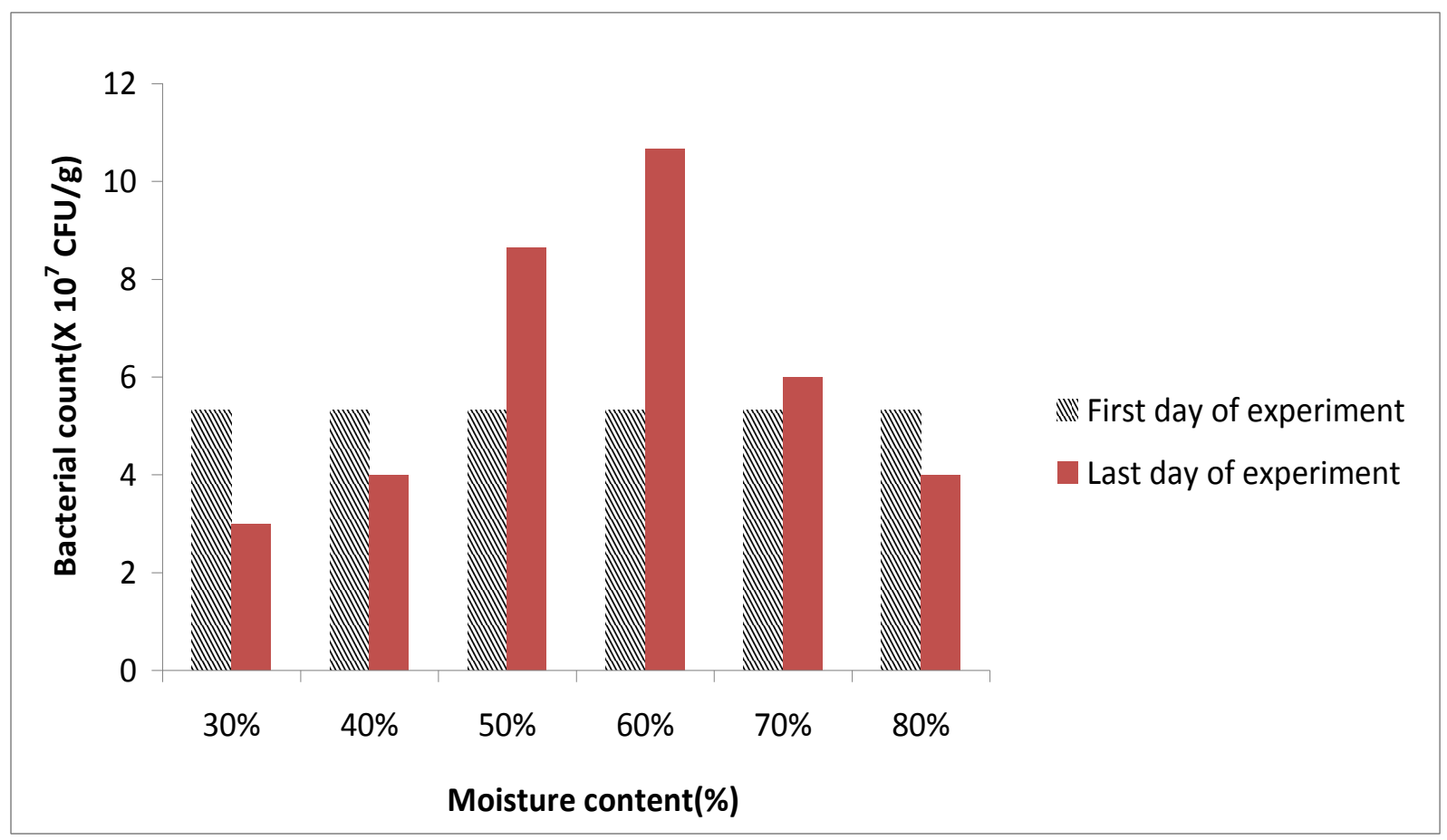

Figure 5: The Bacterial count for the effect of moisture content on $\mathrm{CH}_{4}$ oxidation with addition of bacterial culture.

\section{CONCLUSION}

The isolation and addition of methanotrophic mixed culture to the compost shows an increased in the methane oxidation rate by almost $50 \%$ compared to the control. Temperature also play an important role in methane oxidation rate with addition of the culture at fixed amount where from this study we can conclude that the temperature at $35^{\circ} \mathrm{C}$ shows highest oxidation rate compared to the other temperature $30^{\circ} \mathrm{C}$ to $45^{\circ} \mathrm{C}$. The moisture content also shows highest oxidation rate are at $60 \%$. Therefore the optimal conditions for methane oxidation in this study were temperature of $35^{\circ} \mathrm{C}$ and moisture content of $60 \%$.

\section{ACKNOWLEDGEMENT}

Authors would like to thank all the individuals, involved directly or indirectly in this project for their academics and technical supports. Utmost appreciation is dedicated to Ministry of Science, Technology and Innovation (MOSTI) Science Fund (12-02-03-2077) and University of Malaya PPP (PS297/2010B) for providing Research Grant to carry out this research.

\section{REFERENCES}

1. Agamuthu, P. 2001. Solid Waste: Principles and Management, University Malaya, Kuala Lumpur.ISBN : 983-2085-26-8.

2. Bogner, J and E. Matthews, 2003.Global methane emissions from landfills: New methodology and annual estimates 1980-1996. Global Biogeochemical Cycles 17(2), 1065.

3. IPCC. 2007. Intergovernmental Panel on Climate Change, Climate Change 2007: Introduction. Cambridge University Press, Cambridge, UK.

4. Rodhe, H., A comparison of the contribution of various gases to the greenhouse effect, Sci., 248,1217-1219(1990).

5. Agamuthu P., Fauziah, S.H., and Kahlil Khidzir. 2009.Evolution of Solid Waste Management In Malaysia :Impact and Implications of the Solid Waste Bill, 2007 . Journal of Material Cycles and Waste Management .Volume 11,Number 2 .ISSN:1438-4957 and 1611-8277.

6. Abichou, T., Chanton, J., Powelson, D., Fleiger, J., Escoriaza, S., Lei, Y., Stern, J., 2006. 
Methane flux and oxidation at two types of intermediate landfill covers. Waste Management 26, 1305-1312.

7. Stern, J.C., Chantona, J., Abichou, T., Powelson, D., Yuan, L., Escoriza, S., Bogner, J.,2007. Use of a biologically active cover to reduce landfill methane emissions and enhance methane oxidation. Waste Management 27, 1248-1258

8. Streese, J and R .Stegmann, 2003.Microbial oxidation of methane from old landfill in biofilters. Waste management 23,573-580.

9. Lelieveld , J ., P.J.Crutzen , F.J. Dentener ,1998. Changing concentration, lifetime and climate forcing of atmospheric methane .Tellus 50B,128150 .

10. Hanson, R.S. \& Hanson ,T.E.(1996) .Methanotrophic Bacteria.Microbial .Rev 60:439-471.

11. Borjesson, G., Chanton, J., Svensson, B.H., 2001. Methane oxidation in two Swedish landfill covers measured with carbon-13 to carbon-12 isotope ratios. Journal of Environmental Quality 30, 369-376.

12. Martin ,K., Markus,W ., Eberhard, B.1998. Methanotrophs and Methanogens in Masonry. Applied and Environmental Microbiology 1998: 4530-4532.

13. Hilger, H., Humer, M.,2003. Biotic landfill covers treatments for mitigating methane emissions.Environmental Monitoring and Assessment 84,71-84.

14. Moldes, A., Cendon, Y., Barral ,M.T., 2007. Evaluation of municipal solid waste compost as a plant growing media component ,by applying mixture design. Bioresource Technology 98 : 3069-3075.

15. Chanton J. \& K. Liplay ,2000. Seasonal Variation in Methane Oxidation in a Landfill cover soil as determined by an In situ Stable Isotope Technique.Global Biogeochem. Cycles 14, 51-60.

16. Boeckx, P., O.Van Cleemput, et al.1996. Methane emissions from a landfill and the methane oxidizing capacity of its covering soil.
Soil Biology and Biochemistry 28(10-11): 13971405.

17. Fauziah S.H ., Agamuthu P., Kjeldsen P ., Scheutz C.2004. Landfill gas migration studies at a selected landfill in Malaysia. Malaysia Journal of Science 23 71-77.

18. Humer ,M ., Lechner ,P ., 2001. Microorganisms against the greenhouse effect suitable cover layers for the elimination of methane emissions from landfill. In: Proceedings of Sixth Annual Landfill Symposium of CA, June 2001, 305-309.

19. Barlaz, M.A., Green, R.B., Chanton ,J.P., Goldsmith , C.D., Hater ,G.R . 2004. Biologically active cover for mitigation of landfill gas emissions .Environmental Sciences and Technology 38.4891-4899.

20. De Visscher, A., Schippers, M . And Van Cleemput, O.2001. Short term kinetics response of enhanced methane oxidation in landfill cover soils to environmental factors. Biol. Fert Soil 33:211-237.

21. Bogner ,J., K.Spokas ,et al.1995. Landfill as atmospheric methane sources and sinks.Chemosphere 31(9):4119-4130.

22. Pawloska, M .2008.Reduction of methane emissions from landfill by its microbial oxidation in filter bed.

23. Whalen et al., 1990 S.C. Whalen, W.S. Reeburgh and K.A. Sandbeck, Rapid methane oxidation in a landfill cover soil, Appl. Environ. Microbiol. 56 (1990) (11), pp. 3405-3411.

24. Suman Mor, Alex De Visscher, Khaiwal Ravindra, R.P Dahiya, A.Chandra, Oswald Van Cleemput, 2006. Induction of enhanced methane oxidation in compost: Temperature and moisture response.Waste Management 26(2006), 381-388. Chanton J. \& K. Liplay ,2000. Seasonal Variation in Methane Oxidation in a Landfill cover soil as determined by an In situ Stable Isotope Technique.Global Biogeochem. Cycles 14, 51-60. 